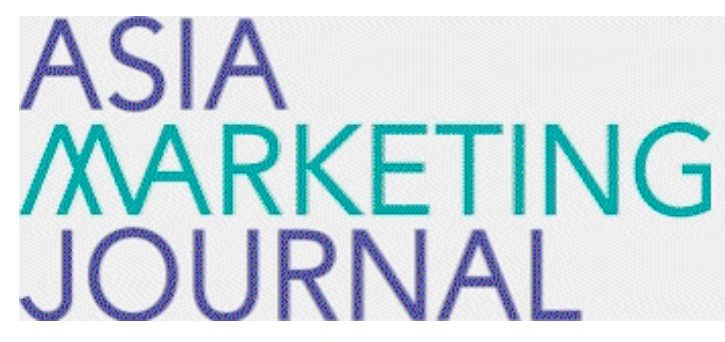

ASIA MARKETING JOURNAL

Volume 19 | Issue 3

Article 2

10-31-2017

\title{
Examining the Impact of Co-branding Service Failures on Consumer Evaluations
}

Chia-Lin Lee

Follow this and additional works at: https://amj.kma.re.kr/journal

Part of the Marketing Commons

\section{Recommended Citation}

Lee, Chia-Lin (2017) "Examining the Impact of Co-branding Service Failures on Consumer Evaluations," Asia Marketing Journal: Vol. 19 : Iss. 3 , Article 2.

Available at: https://doi.org/10.15830/amj.2017.19.3.19

This Article is brought to you for free and open access by Asia Marketing Journal. It has been accepted for inclusion in Asia Marketing Journal by an authorized editor of Asia Marketing Journal. 


\title{
Examining the Impact of Co-branding Service Failures on Consumer Evaluations
}

\author{
Chia-Lin Lee*
}

\begin{abstract}
Researchers do not fully understand consumers' responses to negative co-branding events; thus, they report inconsistent evidence regarding the negative impact on the partnering brands. Our research bridges a gap in this research stream, and answers an important question: When a service failure occurs, could the two different models of consumers' brand schema change affect their negative perception of each brand partner? By using a theoretical and mathematical modeling approach, we offer two propositions. The first proposition shows that, under consumers' book-keeping cognitive process, the negative spillover effect occurs for both brands. The second proposition argues that, when the sub-typing model is assumed, it is possible that one brand suffers while the other escapes the blame for the failure. To our knowledge, this is one of the first few studies to identify circumstances in which a negative spillover effect may or may not occur to brand partners in co-branding service failures.
\end{abstract}

Key words: Co-branding, Service failure, Spillover effect, Brand schema

\section{Introduction}

Co-branding is a topic of increasing importance (Lanseng and Olsen 2012), and the extensive use of co-branded services has been observed (Keiningham et al. 2006; Cao and Sorescu 2013). To our understanding, there is no universally-accepted definition of "co-branded service”. This term most often refers to the combination of two brands' names appearing with a joint-service offering. Marketplace examples include a co-lectured business education program offered by two universities (Naidoo and Hollebeek 2016), the joint sales of Fasturn Co. and Andersen Consulting (Helm and Özergin 2015), Barnes \& Noble and Starbucks (Newmeyer et al. 2014), the KFC/A\&W fast-food restaurant (Walchli 2007), and the Bic Camera home appliance with Uniqlo. In a broader sense, co-

\footnotetext{
* Assistant Professor, Department of Business Administration, National Chengchi University, Taiwan (clee@nccu.edu.tw)
} 
branded services may also include co-located retail stores and hotel chains (e.g., Holiday Inn with TGI Friday's). Recently, co-branded services have seen an explosive growth ( $\mathrm{Li}$ and Murphy 2013a); however, the failure rate of this type of strategic alliance is also high, ranging from 50 to 70 percent (Kaplan et al. 2010).

Co-branding studies have focused primarily on consumer evaluations of tangible products, not services (Helm and Özergin 2015; Naidoo and Hollebeek 2016). Most of these studies have examined how perceived-fits affect consumer evaluations of co-branded products and of each allying brand's products. ${ }^{1)}$ For example, Swaminathan et al. (2012) posited that the trial of a co-branded product with a good fit positively influences the behavioral intentions of the prior non-loyal customers. Van der Lans et al. (2014) showed that a good brand-personality fit is also crucial for positive consumer evaluation. Lee and Decker (2016) reported that, in the case of a moderately incongruent pair, both brands are likely to enhance the attribute-beliefs.

In general, intangible services and tangible goods have some similarities. For instance, both provide solutions to consumer problems; thus, both have functional, affective, and selfexpressive elements for delivering value to consumers (cf. Grönroos 2001; Edvardsson et al. 2005). However, many significant differences between the two also exist, and these differences are often reflected in co-branding strategies (e.g., Dibb and Simkin 1993; Blankson and Kalafatis 1999). We argue that consumers evaluate intangible co-branded services differently from how they evaluate tangible co-branded products. Therefore, we cannot apply most of the research findings on consumer evaluations of co-branded products to co-branded services. To our knowledge, at least three issues hamper this knowledge transfer.

First, most co-branded products are bundled for functional performance, such as Slim-Fast cake mix by Godiva, an example of a highlevel integration (Newmeyer et al. 2014). In this case, consumers could readily attribute the good or bad performance to just one brand. That is, if the cake is delicious, do they attribute this to Slim-Fast or to Godiva? In contrast, the degree of integration in co-branded services ranges from low - where the two brands co-locate their services but consumers purchase their products at separate counters (e.g., Barnes \& Noble with Starbucks) - to moderate or high, where both brands are involved in service preparation (e.g., the shared foodpreparation process of $\mathrm{KFC} / \mathrm{A} \& \mathrm{~W})$. In some co-branded services, consumers may identify which brand to praise or criticize.

1) In this paper, the terms "allying brands" and "partnering brands" are used interchangeably to represent the two brand partners. 
Second, due to the intangible nature of services (Iacobucci 1998), consumers cannot readily inspect and evaluate a service before buying it because they cannot see, feel, or test it (Van Riel et al. 2001). Thus, the brand reputation of the service provider greatly influences consumer choices and subsequent evaluations because consumers rely heavily on brand name as an indicator of good service (Herbig and Milewicz 1995). Therefore, the (in)compatible brand reputation may impact consumer evaluation of intangible services more than that of tangible products.

Third, because the measures of service quality include employees' service attitudes (e.g., courtesy), consumers' attribution of a good (or bad) performance in the service context may differ from that in the tangible product context. For example, when examining consumer evaluations of service quality, we should also consider the relationship between the employee and the customers (cf. Wan et al. 2011) and how the level of interactional justice affects consumer evaluation (e.g., Weber and Sparks 2010). In summary, a deeper examination of co-branded services is required because co-branding marketing knowledge mainly derives from products (Helmig et al. 2008). This paper aims to bridge the gap.

Another concern is that, based on a thorough literature search, co-branding studies generally point to the positive effect of a co-branding alliance on a partnering brand (cf. Washburn et al. 2004). For example, Rao and Ruekert (1994) claimed that a newly-established brand could receive quality signals if it allies with a reputable brand. Levin et al. (1996) reported that both brands may increase the brand value (i.e., brand equity) by forming a co-branding alliance. Simonin and Ruth (1998, p. 39) also reported that the lesser-known brand could gain more from a well-liked and better-known brand partner. Voss and Tansuhaj (1999) investigated the market-entry strategy of a multi-national alliance and showed that a positive impact may occur to a foreign brand, if it pairs with a more reputed domestic brand. Washburn et al. (2004) linked economics of information theory (Stigler 1961) with co-branding alliances, suggesting that the lower-value brand may benefit from allying itself with a higher-value one. Cao and Sorescu (2013) used a time-series model to estimate the market reaction of co-branded consumer goods, and found that both partners could gain financially by approximately $1.0 \%$ in their firm value.

Surprisingly, co-branding research seldom addresses the negative influence of a $\mathrm{co}^{-}$ branding partnership on each brand partner (Woisetschlaeger et al. 2008). Such impact, also called negative spillover effect in this study, may occur in a co-branding product failure (Radighieri et al. 2014) or in an asymmetric partnership (Lee 2014). For example, Janiszewski and van Osselaer (2000) found that the negative impact could occur to 
both brand partners, yet Washburn et al. (2000) demonstrated that a higher-value brand will not suffer negatively from partnering with a lower-value brand partner. Vaidyanathan and Aggarwal (2000) also reported that a more favorable and well-known brand may escape the negative influence of such an alliance. A recent study by Cunha Jr. et al. (2015) posited that a negative impact can occur to a lesserknown brand; however, due to the cue facilitation effect (e.g., Vadillo and Matute 2010), this impact may become positive when the co-branding information is presented after a delay. Thus, the existing co-branding studies on negative spillover effect have also demonstrated inconsistent evidence (Votolato and Unnava 2006, p. 197).

Therefore, our objective is to identify circumstances in which a co-branded service alliance can negatively influence both brand partners, an important research question for which the current research has not yet provided a clear answer (cf. Li and Murphy 2013a; Newmeyer and Ruth 2013). That is, even though marketing alliances may be profitable, if brand managers cannot identify this potential risk in advance, the proposed brand partnership can still be dangerous.

Specifically, we will extend theories from the research stream of brand-schema-change (e.g., Gürhan-Canli and Maheswaran 1998; Park et al. 1991) to investigate, in a co-branding service failure, how the two models of consumers' brand-schema-change affect their negative perception of each brand partner (i.e., negative spillover effect). For example, if a cashier or waiter is rude at a $\mathrm{KFC} / \mathrm{A} \& \mathrm{~W}$ co-branded restaurant, will consumers' different cognitive processes influence their negative perception of each allying brand? This paper employs the theoretical modeling approach (e.g., Stock and Balachander 2005) to investigate the impact of a co-branding service failure. Based on our specific assumptions, our theory-driven propositions specify conditions in which a negative impact may or may not occur to brand partners in a co-branding service failure. Different from Van der Lans et al.'s (2014) decision support model, which performs a real-brand analysis for deriving operational solutions, our modeling approach focuses more on the logical experiments that offer brand managers a strategic rule if the key decision variable changes (Moorthy 1993). Furthermore, compared to Cao and Sorescu (2013)'s time-series model, which places more emphasis on firms' financial returns, our model focuses more on the influences of consumers' psychological characteristics.

Our analysis complements previous findings in three aspects. First, our work complements Park et al. (1996) and Rao and Ruekert (1994, p. 87) by showing that, even in the scenario of attribute-level complementarity, a crucial risk in terms of diluting attribute-beliefs could occur for the co-brand and for each brand partner when a co-branding service failure occurs. We also add to Newmeyer et al.'s (2014) findings 
by providing a normative guideline of how co-branding partners can best react promptly to a service failure. Finally, this research explores the impacts of consumers' individual differences in schema change on the corporate strategy of service recovery (cf. Lin et al. 2016, p. 317).

The remainder of this paper is organized as follows. Section 2 reviews the existing relevant literature on co-branded services, service failures, and brand-schema-change. Section 3 presents two research propositions. Section 4 provides details of the mathematical analytical model and the proof of the propositions. Section 5 describes the present study's conclusion, academic contributions, managerial implications, and limitations.

\section{Literature Review}

\subsection{Co-branded Service and Service Failure}

The term "co-branded service" can be defined as when "two service makers integrate their business processes to provide a service offering and to present it jointly to the customer" (e.g., Li and Murphy 2013b). Co-branding may involve various types of cooperative arrangements (cf. Walchli 2007), and the various definitions of co-branding are sometimes ambiguous (cf.
Tsai et al. 2014). In the following, we introduce, among others, two popular types of co-branding - "ingredient co-branding" and "composite brand extension co-branding", and extend the definitions from the literature regarding tangible co-branded products to the co-branded service context.

Ingredient co-branding, also called component co-branding, is exemplified by the "Intel chip within the HP laptop" case (Venkatesh and Mahajan 1997) and refers to "the use of a branded ingredient or component in a product introduced by another brand" (Norris 1992). In an ingredient co-branding alliance, both brands' products can be physically distinguishable (Newmeyer et al. 2014, p. 105); however, consumers can still perceive each brand's contribution to the offering as relatively distinct. Hence, we argue that for this type of $\mathrm{co}^{-}$ branding alliance, in most cases, consumers can easily recognize and identify which brand to praise or criticize. In the service context, we considered cases where the two brand-partners were minimally, if at all, involved with each other's service preparations, and where consumers could readily identify the source of a positive and negative performance as examples of "ingredient service co-branding" (cf. Helm and Özergin 2015). Barnes \& Noble/Starbucks is a typical example.

The second popular type of co-branding, composite brand extension, can be defined as "a joint presentation of two brands' names to 
create a composite brand name on a new product", exemplified by the example of SlimFast cake mix by Godiva (Park et al. 1996). In this case, consumers usually have difficulty deciding which brand to praise or blame, because both brands' products are partially- or almost-completely-fused in form and utility. How can we tell whether the great taste is due to Slim-Fast or Godiva? To extend this argument into the service context, we consider examples where consumers may not easily recognize each brand's service as a "composite service co-branding”. Therefore, in this study, the $\mathrm{KFC} / \mathrm{A} \& \mathrm{~W}$ co-branded restaurant is considered a typical example of "composite service co-branding". This case, compared with the examples of "ingredient service co-branding", contains more jointly-presented services (e.g., shared food preparation and counter services), and thus, the two brands present a higher level of integration (Newmeyer et al. 2014). In addition, the employees from the two brands perform tasks for both brands, even wearing one uniform that represents both partners. Thus, consumers may have difficulty attributing a good/bad performance to a specific brand.

As mentioned in Section 1, marketing scholars have paid little attention to co-branded services. Hurwitz (1995) appears to be the first to explain how consumers can benefit from a co-branded service. Levin and Levin (2000) used the term "dual-branding" to describe an arrangement in which two brands share the same location, such as two fast-food restaurants that provide a food service together to consumers who can order food from both restaurants at the same counter (e.g., KFC/A\&W). The authors reported that, in this type of co-branded service, consumers tend to perceive a similar level of service quality for both brands. In this study, we categorize "dual-branding" into the "composite service co-branding" because the two brands have some intertwined operational processes.

From a strategic point of view, Venkatesh et al. (2000) and Rahman and Areni (2009) explored the antecedent conditions of a successful co-branded service. A recent study by Newmeyer et al. (2014) utilized attribution and categorization theories to analyze the partner selection decision in the co-branded service context. In summary, scholars have not explicitly mentioned how consumers react to a potential and significant risk in the co-branded service context: the effects of service failures on consumer evaluations of each of the allying brands (Keiningham et al. 2006).

The term "service failure" (e.g., a staff's rude attitude) is an important topic in the service marketing field, and is defined as "any service-related mishaps or problems that occur during a consumer's experience with the firm" (Maxham 2001). A service failure can result in consumers' "negative spillover effect" (hereafter, NSE) to the service provider (Schumann et al. 2014). Extant studies have reported that 
different levels of psychological connections that a customer has with a service provider may moderate the magnitude of consumers' NSE - either a buffering effect (e.g., Mattila 2004; Grégoire and Fisher 2006) or an amplifying effect (e.g., Kaltcheva et al. 2013).

To the best of our knowledge, co-branding researchers have often examined NSE on two levels: the attribute-belief level and the attitude level. For example, by assuming that the consumer evaluation is under a deeper processing (Fishbein and Ajzen 1975), Hillyer and Tikoo (1995) reported that consumers' attribute-belief, in terms of consumers' perceived performance levels, about one brand, may dilute their attribute-belief about the other one through a co-branding partnership. Drawing on the theory of concept specialization (e.g., Murphy 1988), Park et al. (1996, p. 464) showed that a negative influence in terms of an unfavorable evaluation may occur to only one brand partner.

By performing an empirical experiment, Votolato and Unnava (2006) documented NSE on the attitude level. The authors reported that the immoral behavior (e.g., dishonesty) and incompetent information of one brand could be transferred to its partner through a co-branding agreement; the impact of moral failures on the spillover effect is more significant. Suh and Park (2009) investigated whether the favorability of the co-branded product would affect the evaluation of each allying brand.
The result of their empirical experiment showed that, under certain conditions, the attitudinal favorability of the allying brands could be negatively influenced by the evaluation of the co-branded product. By using a hypothetical example (i.e., the Kodak/Nokia camera-mobile), Radighieri et al. (2014) tested how the failure case of co-branded products causes different magnitudes of NSE on the partnering brands; the results indicated that the brand with a higher level of familiarity and favorability could receive less NSE at the attitudinal level.

In sum, co-branding studies on NSE focus mainly on consumer goods, and research on NSE in the co-branded service context is sparse (cf. Helmig et al. 2008). More important, as mentioned in Section 1, co-branding scholars still cannot achieve consensus on the existence of NSE on brand partners.

\subsection{Brand Schema Change}

The term "schema" can be defined as "an internal structure, developed through experience with the world, which organizes incoming information relative to previous experience" (Mandler and Parker 1976, p. 39). Scholars have paid much attention to consumers' schema in marketing research (e.g., Sujan and Bettman 1989; Misra and Beatty 1990; Lynch and Schuler 1994; De Ruyter and Wetzels 2000; Nenycz-Thiel and Romaniuk 2016). In this research stream, all information that consumers 
possess about a brand is called the "brand schema" (e.g., Park et al. 1991; Park et al. 1993: De Ruyter and Wetzels 2000). In particular, both the functional and abstract, image-based associations are considered important components of brand schema (De Ruyter and Wetzels 2000, p. 642). For instance, consumers' schema of the brand of Ivory may include associations such as pure, white, smooth, and gentle. Similarly, the brand schema of "Neutrogena" may include the functional attribute, "mildness" (Loken and Roedder John 1993). In this regard, we consider consumers' perceived performance level of important attributes (i.e., attributebeliefs; Park et al. 1996) a key element of brand schema (De Ruyter and Wetzels 2000). Marketing researchers have explored consumers' brand schema changes in the brand extension field (e.g., Park et al. 1993; Gürhan-Canli and Maheswaran 1998; Sheinin 2000; Luo et al. 2010). New and inconsistent brand information from extended products can link directly to consumers' existing brand schema. Eventually, consumers may change their existing schema (i.e., the spillover effect in this research). To our knowledge, most studies in this research stream have examined the spillover effect on the attribute-belief level (i.e., belief enhancement and dilutions; e.g., Gürhan-Canli and Maheswaran 1998; Desai and Keller 2002).

To the best of our understanding, there are three models of consumers' brand-schema-change. The first is the conversion model, which suggests that consumers' existing schema may change significantly when they receive new and dramatically inconsistent brand information. To the best of our knowledge, compared with the book-keeping and sub-typing models, the conversion model has received less supporting evidence from the lab experiments (cf. GürhanCanli and Maheswaran 1998; Queller and Smith 2002, p. 300; Thorbjørnsen 2005).

The second is the book-keeping model (e.g., Güerhan-Canli and Maheswaran 1998; Luo et al. 2010), which predicts that consumers will integrate a new instance into their existing beliefs and thus change their existing beliefs. Applied to the brand extension context, this model predicts that a brand's new and extended product will cause consumers to revise their existing beliefs about that brand. The more inconsistent a new and extended product is with consumers' existing beliefs about that brand, the larger the consumers' belief dilution will be.

The third is the sub-typing model (e.g., Sheinin 2000). Applied to the brand extension context, the sub-typing model predicts that when the new information is deemed discrepant or inconsistent with existing schema (e.g., Sujan and Bettman 1989; Park et al. 1993; Milberg et al. 1997), consumers will perceive a brand's new and extended product as an atypical extension. For instance, consumers may perceive a new Neutrogena shampoo described as effective and strong as an exceptional product of Neutrogena because they have 
perceived Neutrogena as mild. To extend this example, the more inconsistent a brand's new and extended product is with consumers' existing beliefs about that brand, the smaller the magnitude of belief dilution will be for that brand (e.g., the dilution of Neutrogena's mildness).

Surprisingly little research has applied the brand schema concept to the co-branding context. Considering co-branding as a type of brand extension, Desai and Keller (2002) utilized the sub-typing model to demonstrate that consumers will more favorably evaluate a $\mathrm{co}^{-}$ branded product when its branded component is deemed unique. Vaidyanathan and Aggarwal (2000, p. 223) reported that sub-typing could buffer NSE on the partnering brands. Geylani et al. (2008) argued that the "information discounting" theory (Anderson and Jacobson 1965) is almost similar to the sub-typing model. They employed this theory to investigate how consumers use their beliefs about a new co-brand to revise existing beliefs about the two brands. The authors reported that consumers tended to revise their existing beliefs about the partnering brands less when they considered the new attribute information of the co-branded product to be more inconsistent with their existing beliefs about both brands before co- $^{-}$ branding. To conclude, co-branding researchers still have a lot to learn about how consumers respond to a negative co-branding event (Newmeyer and Ruth 2013).

To bridge this gap, in the following we will apply schema change theory to explore how different models of brand-schema-change affect consumer perceptions in co-branding service failures. More specifically, because existing findings on NSE in the co-branding field have been mixed, we will try to utilize the bookkeeping model and the sub-typing model to specify when NSE affects the brand partners.

\section{Research Propositions}

This section offers two theory-driven propositions for complementing the existing knowledge of NSE in the co-branded service context. We assume that there are two equallyreputed brands in a dual-branding case (e.g., $\mathrm{KFC} / \mathrm{A} \& \mathrm{~W}$ fast-food restaurants). We further assume that consumers will perceive the KFC/ A\&W fast-food restaurant as an extension of each brand (cf. Lei et al. 2008), because they are in the same category of this service (cf. Ward et al. 1992). Furthermore, we suppose that consumers evaluate the two brands on two important "service" attributes for restaurant customers (in comparison with the "food" or "atmosphere" attributes; cf. Kivela et al. 1999), namely politeness (courtesy) and a quick response (fast service). In addition, when consumers experience the new co-branded service, we assume that they tend to first notice the attribute-level information (e.g., 
Samu et al. 1999, p. 59).

The motive for each brand to establish this alliance is attribute-complementarity (i.e., a good-fit; cf. Park et al. 1996): One brand is perceived to excel in the attribute of "good service attitude of staff" or "politeness or courtesy" (e.g., A\&W), while the other (KFC) is perceived to excel in the attribute of "a quick response - fast service". Consumers' perceived performance level of the two attributes (i.e., attribute-beliefs) of the two brands is assumed to be transferred to and integrated into their evaluation of the co-brand (cf. De Ruyter and Wetzels 2000; Geylani et al. 2008).

Supposed that a specific service failure relevant to the two service-related attributes occurs in a co-branded restaurant, such as staff rudeness, and that this failure is considered inconsistent with consumers' existing beliefs about one of the allying brands. For example, a consumer's perceived level of "politeness" of a $\mathrm{KFC} / \mathrm{A} \& \mathrm{~W}$ waiter is lower than what she or he expected for the waiter in this co-branded restaurant; thus, the consumer deems the waiter's rude behavior to be a failure. That is, the reference point of this failure is the consumer's expected beliefs about the "politeness" of this co-branded restaurant. ${ }^{2)}$ Our first proposition (Prop. 1) applies the book-keeping model (e.g., Gürhan-Canli and Maheswaran 1998; Hsu et al. 2013), and is stated in the following.

\subsection{Proposition 1}

When a service failure occurs and when the book-keeping cognitive process is assumed, the failure will dilute consumers' beliefs about both partnering brands. The larger the inconsistency of the failure is, the larger the consumers' dilution will be.

Prop. 1 predicts that consumers who follow the book-keeping cognitive process will negatively revise their existing beliefs about both partnering brands (i.e., they will lower their opinion of both brands) when a service failure inconsistent with their existing beliefs occurs. Eventually, both brands will suffer from NSE. This proposition clearly explains that a negative influence on the brand partners still occurs in the good-fit scenario (i.e., attribute complementarity).

In contrast, the second proposition (Prop. 2) is relevant to the sub-typing model (e.g., Gürhan-Canli and Maheswaran 1998; Loken and Joiner 1998; Vaidyanathan and Aggarwal 2000). It is described as follows.

2) Geylani et al. (2008) showed that the expected co-branding beliefs are formed by averaging the existing performance levels of both brands. Thus, the referencing point of the failure is consumers' existing attribute-beliefs about both brands. 


\subsection{Proposition 2}

When a service failure occurs, under the sub-typing cognitive process, that failure will dilute consumers' beliefs about the partnering brand. The larger the inconsistency of the failure is, the smaller the consumers' dilution will be. In an extreme case, a free-rider problem may occur.

Prop. 2 applies the sub-typing model, and posits that consumers under the sub-typing model will discount the influence of the failure: the larger the inconsistency, the lesser the magnitude of the belief dilution. In this scenario, we argue that, when consumers consider the failure to be extremely-inconsistent with their existing beliefs about one brand, they will tend not to negatively revise their existing beliefs of that brand. For example, when a "very-rude" staff attitude occurs, consumers may assume that this rudeness is atypical of $A \& W$. Consequently, they may consider the failure an exception to A\&W's service, and may have no belief dilution on $A \& W$. In short, sub-typing leads to a completely-buffering effect of NSE for A\&W. This extreme case clearly explains how a crucial problem within a co-branding alliance may occur: the freerider problem (Simonin and Ruth 1998; Venkatesh et al. 2000). Noted that Prop. 1 and Prop. 2 cannot exist simultaneously. That is, we assume that an individual consumer cannot have both types of cognitive processes at the same time. Also due to the need for parsimony, we assume that the two brands are equally-reputed, and we will relax this assumption to offer more managerial implications in Section 5.3.

In sum, our propositions clarify the inconsistent evidence of NSE in the literature. To our knowledge, Lee (2015) also identified the occurrence of NSE; the author investigated the influence of customer empathy on consumers' attribution process by utilizing the otherreferencing concept. However, the research stream addressing the other-referencing (or self-referencing) concept seldom appears in the branding literature. Different from Lee (2015), this research follows the brand-schemachange research stream, a major and currently still important concept in the branding research field (e.g., Carsana and Jolibert 2017). So, our study extends existing knowledge of brand schema to the research area of co-branded service, thus opening fresh avenues for future exploration of brand-schema-change in a co- $^{-}$ branded service setting. Moreover, unlike the Lee (2015)'s study, this research puts a stronger focus on discussing the distinct characteristics of different types of co-branded services; one could further adapt our model to provide more important propositions applicable in other co-branding scenarios. 


\section{Research Method}

\subsection{Model Setting}

We will use the theoretical modeling approach for proving our propositions. In doing so, we can provide managers with crucial variables and help them make a better strategy (cf. Miklós-Thal 2012). Our model identifies the occurrence of NSE in a specific co-branding service failure. In comparison with the dynamic updating models in the service marketing field (e.g., Bolton 1998; Rust et al. 1999), our model emphasizes more on the static influence (i.e., two periods: before and after co-branding) of consumers' perceptions for providing more details about the existence of NSE in consumers' mind.

We use the expectancy-value model (cf. Bass and Talarzyk 1972) to formulate consumers' NSE, because Mittal et al. (1998, p. 33) posited that multi-attribute attitude formation is best-suited for modeling consumers' perceptions of services. In addition, this model has been extensively-used to formulate consumers' reactions to a service failure in the service marketing field. Earlier investigations in this field have adapted this type of model to set up a quantitative measure of satisfactions (e.g., Teas 1993; Kivela et al. 1999). However, by addressing this multi-attribute type of attitude formation, we may lose the opportunity to assess the influence of other factors on consumers' attitudes and brand assessments (e.g., Oliver 1980).

Supposed that two prospective brands intend to establish an exclusive "dual-branding" restaurant (Levin and Levin 2000), and we use $\eta(\eta \in\{A, B\})$ to indicate the two brands. At a single shared location, $A$ and $B$ use the same kitchen to prepare food, and the customers can order both brands' food at the same counter. We further assume that the restaurant staffs are from the two brands, but the customers cannot differentiate one from the other (i.e., the same uniform). Assuming further that we consider only two customer segments that prefer $A$ and $B$ respectively (i.e., the current customers). Note that, ideally, except for their current customers, this co-brand could also target an unoccupied or overlooked segment. Two reasons underlie this assumption. First, we wanted to address that, for each brand, an important objective is to retain current customers, because the cost of attracting new customers is possibly higher than that of keeping an old one (Peppard 2000). The second reason is that, similar to Venkatesh et al. (2000), due to the need for parsimony of the mathematical modeling approach, this paper focuses only on the evaluation of existing customers.

Assuming further that, at time point $i=1$, the co-branded restaurant is formed. At $i=2$, a service failure already occurs, and the customers soon notice it and the customers' NSE occurs 
for each brand. Furthermore, we use $G(G \in$ $\{x, y\})$ to denote two important "service" attributes (Kivela et al. 1999). For instance, $x$ represents the "good service attitude" (politeness) and y represents "a quick response" (fast service). We also assume that $A(B)$ is known by all the customers in which staff perform well on $x(y)$ but not $y(x)$ at $i=1$. That is, $A(B)$ is referred to as $A \& W(K F C)$ in our scenario. By using the expectancy-value model, we formulate the customers' preference, $\theta_{\eta(i)}$, at time $i$, as a relative value (cf. Bolton 1998) consisting of their relative weights of attribute importance $\varepsilon^{G}>0$, and their beliefs of each attribute of each brand, $W_{\eta(i)}^{G}>0$ (cf. Fishbein and Ajzen 1975); the customers' expected co-branding beliefs $\left(W_{A B}^{G}\right.$ ) can be modeled by presenting a mixed process of existing beliefs about the two brands (Geylani et al. 2008).

However, the customers' expected performance may be different from their perceived performance (Grönroos 1998). Thus, $P_{A B}^{G}$ denotes the perceived performance, and $d^{G}$ denotes the gap between expected and perceived attribute performance. That is,

$$
d^{G}=\left|W_{A B}^{G}-P_{A B}^{G}\right| .
$$

Note that $d^{G}$ also denotes a service failure relevant to the two attributes when $W_{A B}^{G}>$ $P_{A B}^{G}$. For example, the customers' perceived degree of "politeness" of a waiter at $\mathrm{KFC} / \mathrm{A}$
$\& W$ is lower than their expected level of "politeness" from this co-branded restaurant, thus a failure (i.e., a rude attitude) occurs. Additionally, the lower the perceived performance level $\left(P_{A B}^{G}\right)$ is, the larger the severity (i.e., extremeness) of the failure.

Finally, the customers' post-alliance evaluation of each brand can be formulated with an updating process using their pre-alliance and co-branding evaluations (cf. Geylani et al. 2008: Song 2017). That is, we assume that the customers form their post-alliance attributebeliefs of the two brands by combining their perceived co-branding beliefs with their prealliance beliefs. Eq. (2) shows customers' updating process of each attribute of each brand:

$$
W_{\eta(2)}^{G}=\delta_{\eta}^{G} \times P_{A B}^{G}+\left(1-\delta_{\eta}^{G}\right) \times W_{\eta(1)}^{G} .
$$

In Eq. (2), we use $\delta_{\eta}^{G}\left(1 \geq \delta_{\eta}^{G} \geq 0\right)$ to denote the updating weight, and the different value of $\delta_{\eta}^{G}$ shows different magnitudes of NSE on the attribute-belief level of two brands (cf. Gürhan-Canli and Maheswaran 1998; Desai and Keller 2002).

\subsection{Proofs}

First, we assume that a service failure relevant to the two service-related attributes occurs and that it is inconsistent with the customers' existing beliefs. Thus, one can write: 


$$
d^{G} \in R^{+} \text {, and } P_{A B}^{G}<W_{A B}^{G} .
$$

Prop. 1 states that, consequently, the customers tend to attribute this failure to both brands. So, eventually the customer's preference score of each brand decreases after the alliance is established (i.e., the occurrence of NSE). Mathematically speaking,

$$
\theta_{\eta(2)}<\theta_{\eta(1)}
$$

Assuming that the customer's preference score follows the multi-attribute nature, and $\varepsilon^{G}$ remains the same after co-branding, the customer's post-alliance preference score $\left(\theta_{\eta(2)}\right)$ can be formulated as:

$$
\theta_{\eta(2)}=\sum_{G} \varepsilon^{G} \times W_{\eta(2)}^{G} .
$$

From Eq. (5), one can confirm that

$$
\partial \theta_{\eta(2)} / \partial W_{\eta(2)}^{G}>0 .
$$

Accordingly, assuming all other variables are equal in Eq. (2), one can realize that the customer's post-alliance beliefs $\left(W_{\eta(2)}^{G}\right)$ relate positively to the increased perceived performance level $\left(P_{A B}^{G}\right)$ :

$$
\partial W_{\eta(2)}^{G} / P_{A B}^{G}>0 .
$$

By referring to Eqs. (1) and (3), one can easily confirm that $\partial P_{A B}^{G} / \partial d^{G}<0$. Thus, the post-alliance beliefs $\left(W_{\eta(2)}^{G}\right)$ relate negatively to the increased severity level of the failure:

$$
\partial W_{\eta(2)}^{G} / \partial d^{G}<0 .
$$

The central tenet of Prop. 1 is that the larger the inconsistency of the failure is, the larger the consumers' belief dilution will be. In view of our above formulation, the necessary conditions for Prop. 1 are

$$
\begin{aligned}
& \partial \delta_{A}^{G} / \partial d^{G}>0, \\
& \partial \delta_{B}^{G} / \partial d^{G}>0 .
\end{aligned}
$$

Indeed, Eqs. (9) and (10) show that the book-keeping cognitive process is in effect. Prop. 2 shows that, in an extreme case, the customers tend to not attribute the failure to one brand. So, mathematically speaking, the post-alliance preference score of one brand (assuming brand $A$ ) is the same as the prealliance preference score:

$$
\theta_{A(2)}=\theta_{A(1)} .
$$

As mentioned above, the underlying reason for this unchanged preference is the extremeness of a co-branding failure (e.g., a very-rude staff attitude), That is, the severity level of the failure $\left(d^{G}\right)$ is extremely high. So, we can formulate the extremeness of the failure by

$$
d^{G} \rightarrow+\infty
$$

Lee and Decker (2016, p.555) have 
mathematically proved that, under consumers' sub-typing process, an event which is extremely different from consumers' current brand schema (e.g., the very-rude staff attitude in our study) can lead to no changes on their existing attribute-beliefs. So, here we follow the logic of proofs of Lee and Decker (2016). That is, Prop. 2 could be proved if the following conditions hold:

$$
\begin{aligned}
& \partial \delta_{A}^{G} / \partial d^{G}<0, \\
& \partial \delta_{B}^{G} / \partial d^{G}<0 .
\end{aligned}
$$

In fact, Eqs. (13) and (14) present the sub-typing model. In conclusion, when this specific cognitive process operates and in an extreme case (e.g., a "very-rude" staff attitude at $\mathrm{KFC} / \mathrm{A} \& \mathrm{~W}$ ), the customers may consider this failure atypical of one of the brands (e.g., A\&W). Eventually, the customers may attribute this failure to the other one (e.g., KFC). So, one brand $(\mathrm{KFC})$ suffers, and the other $(\mathrm{A} \& \mathrm{~W})$ avoids the blame for the failure: a free-rider problem occurs.

\section{Conclusion, Contributions, and Possible Extensions}

\subsection{Main Findings}

This study explores consumers' responses to a co-branding service failure. Specifically, we use a theoretical modeling approach to provide a micro-level explanation of the mechanism behind how consumers' brand-schema-change affects their NSE on the partnering brands. We ask whether the book-keeping or sub-typing model magnifies or mitigates NSE for the brands in a co-branding service failure. We show that, under the book-keeping cognitive process, if the failure is inconsistent with consumers' existing brand schema (i.e., attributebeliefs) of the partnering brand, both brands will suffer from NSE. In contrast, when subtyping is used, if the failure is extremelyinconsistent with consumers' existing brand knowledge, they tend to attribute the failure to only one brand partner. Note that, however, our results are applicable only to our example, and cannot be generalized for all the other co-branding arrangements (e.g., ingredient service co-branding).

\subsection{Theoretical Contributions}

This paper's theoretical contributions are twofold. First, this study is one of the first few to address consumer attribution in co-branding service failures. Specifically, we identify conditions in which NSE may or may not exist in a co-branding service failure. Our result confirms that NSE may only affect one brand (cf. Park et al. 1996: Washburn et al. 2000), and, more important, we show a free-rider problem in 
co-branding service failures - if a co-branding service failure occurs, it can reflect poorly only on one partner brand (cf. McKee 2009).

Second, we enhance co-branding research by illuminating the influence of the "intangibility" characteristic of co-branded services. Unlike physical goods, services are often regarded as an intangible and dynamic value co-creation process (e.g., Grönroos 2006; Brodie et al. 2009). For example, a service encounter between a customer and an employee (e.g., the perceived service attitude or the speed of a service), albeit intangible, has an important influence on a service brand's value. In this regard, we report that employees' bad service attitude could hurt the value of the allying brand(s) if NSE occurs. In a broader sense, the decreased brand value can subsequently affect the equity of the partnering brand(s) (e.g., the brand value co-creation model; Merz et al. 2009).

\subsection{Managerial Implications}

Our results show two implications for brand managers. First, Prop. 2 and its argumentation remind alliance partners of the free-rider problem caused by a service failure. This problem is particularly crucial for brand partners when the partnership is newly-established (i.e., the perceived quality is not yet stable; Rust et al. 1999), and this problem is the worst scenario in a partnership - only one brand suffers from the failure. We argue that one way to minimize the negative impact on the suffering brand is to increase consumers' familiarity with it (cf. Alba and Hutchinson 1987). Cobranding researchers have reported that the brand with a higher level of familiarity receives a smaller NSE (e.g., Baumgarth 2004). In this regard, in our scenario of Prop. 2, the customers' NSE on KFC could be mitigated if the level of brand familiarity were high. Practically, consumers' familiarity with one brand can be enhanced with frequent exposure to that brand (e.g., advertisements of the co-branded products; cf. Park and Stoel 2005).

Second, we can relax the assumption of equal reputation (cf. brand awareness, Kim et al. 2015) in Section 3 to offer one more practical implication. Prop. 1 posits that, when consumers follow the book-keeping process and when consumers consider a failure inconsistent with their current brand knowledge, they may attribute this failure to both brands. In this case, we argue that the brand with the weaker reputation could suffer more than the brand with the stronger reputation. Prop. 2 states that, when sub-typing thinking is assumed and when the failure is considered extremely-inconsistent, the consumers tend to consider this failure atypical. In this scenario, a free-rider problem possibly occurs with the more-reputed brand, because consumers usually consider this failure atypical to the more-reputed brand (cf. Lei et al. 2012). In sum, the less-reputed brand may have more difficulty protecting its reputation 
in co-branding service failures. We suggest that the less-reputed brand should consider this possible disadvantage when forming an alliance with a more-reputed brand (cf. Washburn et al. 2000). That is, different from Simonin and Ruth (1998, p. 39), Washburn et al. (2004, p. 495), Bengtsson and Servais (2005), and Kalafatis et al. (2012), we find that the lower-status (e.g., weaker reputation) brand may not always benefit from its partner; instead, it could suffer more than the higher-status (e.g., stronger-reputation) brand.

\subsection{Research Limitations and Future Research Directions}

This study is not without limitations. First and foremost, the present research mainly focuses on the service partnership, and therefore does not include the cases of product-service co-branding, such as HTC mobile co-branded with a telecommunications service provider (e.g., Sprint; cf. Chen and Bei 2011), HaagenDazs ice cream co-branded with AirAsia's in-flight service (cf. Shugan et al. 2017), or the hypothetical headsets co-branded by AKG and Starbucks for improving customers' musiclistening experiences in the coffee shop. We argue that, when a negative (or positive) event occurs in the product-service partnership, the level of integration between brands determines consumers' attribution of responsibility. To the best of our knowledge, in most of the productservice alliances the two brands are nearly separate in form and function. We expect that, when the bond between brands is weak, consumers can assign blame (or credit) only to the brand responsible for the bad (or good) performance (cf. Newmeyer et al. 2014) under both cognitive processes discussed in this research. Future studies could explore and validate this interesting issue."

Second, a major research area in the field of brand extension focuses on whether consumers' brand schema can change on the belief level (i.e., belief change), and, if so, the amount of belief change (e.g., Gürhan-Canli and Maheswaran 1998; Desai and Keller 2002). By assuming that co-branding is a type of brand extension (Hadjicharalambous 2006), this research aims to (1) investigate whether consumers' attribute-beliefs may or may not change following a co-branding service failure, and (2) formulate the magnitude of this belief change. By assuming the multi-attribute nature (cf. Srivasan 1979; Lee 2014), we argue that the major cause of attitude change is a change in attribute-beliefs. Thus, when sub-typing is used, in the extreme case, consumers' beliefs will not change, and the associated attitude will remain the same.

Third, as mentioned in Section 5.1, we claim that our propositions may not be applicable to

3) The author thanks one of the anonymous reviewers for pointing out this important issue. 
"ingredient service co-branding". Two arguments underlie this claim. First, as already mentioned in Section 2.1, in a service failure, consumers are less likely to apportion blame to both partners and can easily recognize which brand to criticize in "ingredient service co-branding" (e.g., Barnes \& Noble/Starbucks). So, the attribution process of the individual customer in "ingredient service co-branding" could be much simpler than that in "composite service co-branding". Our propositions are effective only when consumers have difficulty identifying the locus (cf. Weiner 2000) of the co-branded service performance. In addition, some ingredient co-branded services are established mainly the business customers (e.g., the joint-sales of Fasturn Co. and Andersen Consulting). Because significant differences exist between the attribution processes of the organizational and individual customer (cf. Homburg and Fürst 2005), the aim of the current research is to address only the importance of the individual customer's attribution. We chose not to discuss both perspectives in this study, but organizational attribution process is a promising area for future research.

Finally, this paper employs the theoretical and mathematical modeling approach for providing brand managers with strategic guidelines regarding the reactions to a co-branding service failure. Thus, our propositions are valid only under the specific model assumptions, and the lack of an empirical validation is a major weakness of this paper. To bridge this gap, future research can first include more key variables in consumer evaluations of restaurant services (e.g., staffs' food knowledge, sympathetic dealing with complaints; cf. Kivela et al. 1999). Then, our formulation of belief change in Section 4.1 can be further adapted into a regression model (e.g., Kivela et al. 1999) or an econometric model (e.g., Bolton and Myers 2003) for providing a more realistic and comprehensive analysis. Overall, this study has illuminated the influences of brand-schemachange on consumer attribution in a service failure context.

〈Received May 12. 2017〉

〈Accepted October 27. 2017〉

\section{References}

Alba, J. W., \& Hutchinson, W. J. (1987). Dimensions of consumer expertise. Journal of Consumer Research, 13(4), 411-454.

Anderson, N. H., \& Jacobson, A. (1965). Effect of stimulus inconsistency and discounting instructions in personality impression formation. Journal of Personality and Social Psychology, 2(4), 531-539.

Bass, F. M., \& Talarzyk, W. W. (1972). An attitude model for the study of brand preferences. Journal of Marketing Research, 9(1), 93-96. 
Baumgarth, C. (2004). Evaluations of co-brands and spill-over effects: further empirical results. Journal of Marketing Communications, 10(2), 115-131.

Bengtsson, A., \& Servais, P. (2005). Co-branding on industrial markets. Industrial Marketing Management, 34(7), 706-713.

Blankson, C., \& Kalafatis, S. P. (1999). Issues and challenges in the positioning of service brands: a review. Journal of Product \& Brand Management, 8(2), 106-118.

Bolton, R. N. (1998). A dynamic model of the duration of the customer's relationship with a continuous service provider: the role of satisfaction. Marketing Science, 17(1), 45-65.

Bolton, R. N., \& Myers, M. B. (2003). Pricebased global market segmentation for services. Journal of Marketing, 67(3), 108128.

Brodie, R. J., Whittome, J. R. M., \& Brush, G. J. (2009). Investigating the elements of the service brand: a customer value perspective. Journal of Business Research, 62(3), 345-355.

Cao, Z., \& Sorescu, A. (2013). Wedded bliss or tainted love? Stock market reactions to the introduction of cobranded products. Marketing Science, 32(6), 939-959.

Carsana, L., \& Jolibert, A. (2017). The effects of expertise and brand schematicity on the perceived importance of choice criteria: a Bordeaux wine investigation. Journal of
Product \& Brand Management, 26(1), 80-90.

Chen, S.-F., \& Bei, L.-T. (2011). HTC corporation: a smartphone pioneer from Taiwan. Ontario, Canada: Ivey Publishing. Cunha Jr., M., Forehand, M. R., \& Angle, J. W. (2015). Riding coattails: when $\mathrm{co}^{-}$ branding helps versus hurts less-known brands. Journal of Consumer Research, 41(5), 1284-1300.

De Ruyter, K., \& Wetzels, M. (2000). The role of corporate image and extension similarity in service brand extensions. Journal of Economic Psychology, 21(6), 639-659.

Desai, K. K., \& Keller, K. L. (2002). The effects of ingredient branding strategies on host brand extendibility. Journal of Marketing, 66(1), 73-93.

Dibb, S., \& Simkin, L. (1993). The strength of branding and positioning in services. International Journal of Service Industry Management, 4(1), 25-35.

Edvardsson, B., Gustafsson, A., \& Roos, I. (2005). Service portraits in service research: a critical review. International Journal of Service Industry Management, 16(1), 107121.

Fishbein, M., \& Ajzen, I. (1975). Belief, Attitude, Intention and Behavior: An introduction to Theory and Research. Reading, MA: Addison-Wesley.

Geylani, T., Inman, J. J., \& Hofstede, F. T. (2008). Image reinforcement or impairment: 
the effects of co-branding on attribute uncertainty. Marketing Science, 27(4), 730-744.

Grégoire, Y., \& Fisher, R. (2006). The effects of relationship quality on customer retaliation. Marketing Letters, 17(1), 31-46.

Grönroos, C. (1998). Marketing services: the case of a missing product. Journal of Business \& Industrial Marketing, 13(4/5), 322-338.

Grönroos, C. (2001). Service Management and Marketing: A Customer Relationship Management Approach (2nd ed.). Hoboken, NJ: Wiley.

Grönroos, C. (2006). Adopting a service logic for marketing. Marketing Theory, 6(3), 317-333.

Gürhan-Canli, Z., \& Maheswaran, D. (1998). The effects of extensions on brand name dilution and enhancement. Journal of Marketing Research, 35(4), 464-473.

Hadjicharalambous, C. (2006). A typology of brand extensions: positioning cobranding as a sub-case of brand extensions. Journal of American Academy of Business, 10(1), 372-377.

Helm, S. V., \& Özergin, B. (2015). Service inside: the impact of ingredient service branding on quality perceptions and behavioral intentions. Industrial Marketing Management, 50, 142-149.

Helmig, B., Huber, J. A., \& Leeflang, P. S. H. (2008). Co-branding: the state of the art.
Schmalenbach Business Review, 60(4), 359-377.

Herbig, P., \& Milewicz, J. (1995). The relationship of reputation and credibility to brand success. Journal of Consumer Marketing, $12(4), 5-10$.

Hillyer, C., \& Tikoo, S. (1995). Effect of cobranding on consumer product evaluations. Advances in Consumer Research, 22(1), 123-137.

Homburg, C., \& Fürst, A. (2005). How organizational complaint handling drives customer loyalty: an analysis of the mechanistic and the organic approach. Journal of Marketing, 69(3), 95-114.

Hsu, Y.-H., Fang, W., \& Kao, Y.-C. (2013). The effect of the advertisement for brand extensions and consumer involvement on the brand attitude and purchase intention of flagship product. Journal of Management and Systems, 20(4), 637-663.

Hurwitz, A. (1995). Co-branding: managing franchise brand associations. Oklahoma City University Law Review, 20, 373-389. Iacobucci, D. (1998). Services: what do we know and where shall we go? A view from marketing, In T. A. Swartz, D. E. Bowen, \& S. W. Brown (Eds.), Advances in Service Marketing and Management, 7: 1-96. Greenwich, CT: JAI Press.

Janiszewski, C., \& Van Osselaer, S. M. (2000). A connectionist model of brand-quality associations. Journal of Marketing Research, 
37(3), 331-350.

Kalafatis, S. P., Remizova, N., Riley, D., \& Singh, J. (2012). The differential impact of brand equity on B2B co-branding. Journal of Business \& Industrial Marketing, 27 (8), 623-634.

Kaltcheva, V. D., Winsor, R. D., \& Parasuraman, A. (2013). Do customer relationships mitigate or amplify failure responses?. Journal of Business Research, 66(4), 525-532.

Kaplan, R. S., Norton, D. P., \& Rugelsjoen, B. (2010). Managing alliances with the balanced scorecard. Harvard Business Review, 88 (1), 114-120.

Keiningham, T. L., Aksoy, L., Tor Wallin, A., Cooil, B., \& Wahren, B. J. (2006). Call center satisfaction and customer retention in a co-branded service context. Managing Service Quality, 16(3), 269-289.

Kim, C., Seo, E., Hong, J., Kang, S., \& Newell, S. J. (2015). The antecedents and consequences of effective brand positioning. Asia Marketing Journal, 17(3), 33-51.

Kivela, J., Inbakaran, R., \& Reece, J. (1999). Consumer research in the restaurant environment, part 1: a conceptual model of dining satisfaction and return patronage. International Journal of Contemporary Hospitality Management, 11(5), 205-222.

Lanseng, E. J., \& Olsen, L. E. (2012). Brand alliances: the role of brand concept consistency. European Journal of Marketing, 46(9), 1108-1126.
Lee, C.-L. (2014). Is co-branding a doubleedged sword for brand partners?. European Research Studies, 17(4), 19-34.

Lee, C.-L. (2015). Negative spillover effects in co-branding service failures: the role of self and other referencing. British Journal of Economics, Finance and Management Sciences, 10(2), 72-81

Lee, C.-L., \& Decker, R. (2016). Co-branding partner selection: the importance of belief revision. Journal of Business Economics and Management, 17(4), 546-563.

Lei, J., Dawar, N., \& Gürhan-Canli, Z. (2012). Base-rate information in consumer attributions of product-harm crises. Journal of Marketing Research, 49(3), 336-348.

Lei, J., de Ruyter, K., \& Wetzels, M. (2008). Consumer responses to vertical service line extensions. Journal of Retailing, 84(3), 268-280.

Levin, A. M., Davis, J. C., \& Levin, I. (1996). Theoretical and empirical linkages between consumers' responses to different branding strategies. Advances in Consumer Research, 23, 296-300.

Levin, I. P., \& Levin, A. M. (2000). Modeling the role of brand alliances in the assimilation of product evaluations. Journal of Consumer Psychology, 9(1), 43-52.

Li, N., \& Murphy, W. G. (2013a). Prior consumer satisfaction and alliance encounter satisfaction attributions. Journal of Consumer Marketing, 30(4), 371-381. 
Li, N., \& Murphy, W. G. (2013b). Consumers' alliance encounter satisfaction, attributions, and behavioral intentions. Journal of Consumer Marketing, 30(6), 517-529.

Lin, J.-S. C., Lin, C.-Y., \& Chou, E.-Y. (2016). Service experience management in Asia: a review and directions for future research. NTU Management Review, 26(2), 303-352.

Loken, B., \& Joiner, C. (1998). The negative impact of extensions: can flagship products be diluted?. Journal of Marketing, 62(1), 19-32.

Loken, B., \& Roedder John, D. (1993). Diluting brand beliefs: when do brand extensions have a negative impact. Journal of Marketing, 57(3), 71-84.

Luo, L., Chen, X., Han, J., \& Park, C. W. (2010). Dilution and enhancement of celebrity brands through sequential movie releases. Journal of Marketing Research, 47(6), 1114-1128.

Lynch, J., \& Schuler, D. (1994). The matchup effect of spokesperson and product congruency: a schema theory interpretation. Psychology \& Marketing, 11(5), 417-445.

Mandler, J. M., \& Parker, R. E. (1976). Memory for descriptive and spatial information in complex pictures. Journal of Experimental Psychology, 2(1), 38-48.

Mattila, A. S. (2004). The impact of service failures on customer loyalty: the moderating role of affective commitment. International Journal of Service Industry Management,
15(2), 134-149.

Maxham, J. G. (2001). Service recovery's influence on consumer satisfaction, positive word-of-mouth, and purchase intentions. Journal of Business Research, 54(1), 11-24. McKee, S. (2009). The pros and cons of cobranding. http://www.bloomberg.com/ news/articles/2009-07-10/the-pros-andcons-of-co-branding. Accessed Feb. 20, 2017.

Merz, M. A., He, Y., \& Vargo, S. L. (2009). The evolving brand logic: a servicedominant logic perspective. Journal of the Academy of Marketing Science, 37(3), 328-344.

Miklós-Thal, J. (2012). Linking reputations through umbrella branding. Quantitative Marketing and Economics, 10(3), 335-374.

Milberg, S. J., Park, C. W., \& McCarthy, M. S. (1997). Managing negative feedback effects associated with brand extensions: the impact of alternative branding strategies. Journal of Consumer Psychology, 6(2), 119-140.

Misra, S., \& Beatty, S. E. (1990). Celebrity spokesperson and brand congruence: an assessment of recall and affect. Journal of Business Research, 21(2), 159-173.

Mittal, V., Ross, W. T., \& Baldasare, P. M. (1998). The asymmetric impact of negative and positive attribute-level performance on overall satisfaction and repurchase intentions. Journal of Marketing, 62(1), 
33-47.

Moorthy, K. S. (1993). Theoretical modeling in marketing. Journal of Marketing, 57(2), 92-106.

Murphy, G. L. (1988). Comprehending complex concepts. Cognitive Science, 12(4), 529562.

Naidoo, V., \& Hollebeek, L. D. (2016). Higher education brand alliances: investigating consumers' dual-degree purchase intentions. Journal of Business Research, 69(8), 31133121.

Nenycz-Thiel, M., \& Romaniuk, J. (2016). Understanding premium private labels: a consumer categorisation approach. Journal of Retailing and Consumer Services, 29, $22-30$.

Newmeyer, C., \& Ruth, J. (2013). Cobrand harm crisis and consumer attributions of responsibility. Advances in Consumer Research, 41, 417.

Newmeyer, C., Venkatesh, R., \& Chatterjee, R. (2014). Co-branding arrangements and partner selection: a conceptual framework and managerial guidelines. Journal of Academy of Marketing Science, 42(2), 103-118.

Norris, D. G. (1992). Ingredient branding: a strategy option with multiple beneficiaries. Journal of Consumer Marketing, 9(3), 19-31.

Oliver, R. L. (1980). A cognitive model of the antecedents and consequences of satisfaction decisions. Journal of Marketing Research, 17(4), 460-469.

Park, C. W., Jun, S. Y., \& Shocker, A. D. (1996). Composite branding alliances: an investigation of extension and feedback effects. Journal of Marketing Research, 33(4), 453-466.

Park, C. W., McCarthy, M. S., \& Milberg, S. J. (1993). The effects of direct and associative brand extension strategies on consumer response to brand extensions. Advances in Consumer Research, 20, 28-33.

Park, C. W., Milberg, S., \& Lawson, R. (1991). Evaluation of brand extensions: the role of product-level similarity and brand concept consistency. Journal of Consumer Research, 18(2), 185-193.

Park, J., \& Stoel, L. (2005). Effect of brand familiarity, experience and information on online apparel purchase. International Journal of Retail \& Distribution Management, 33 (2), 148-160.

Peppard, J. (2000). Customer relationship management (CRM) in financial services. European Management Journal, 18(3), 312-327.

Queller, S., \& Smith, E. R. (2002). Subtyping versus bookkeeping in stereotype learning and change: connectionist simulations and empirical findings. Journal of Personality and Social Psychology, 82(3), 300-313.

Radighieri, J. P., Mariadoss, B. J., Grégoire, Y., \& Johnson, J. L. (2014). Ingredient branding 
and feedback effects: the impact of product outcomes, initial parent brand strength asymmetry, and parent brand role. Marketing Letters, 25(2), 123-138.

Rahman, K., \& Areni, C. (2009). Service brand relationship matrix: brand strategy for services. World Journal of Management, 1(1), 141-152.

Rao, A. R., \& Ruekert, R. W. (1994). Brand alliances as signals of product quality. Sloan Management Review, 36(1), 87-97.

Rust, R. T., Inman, J. J., Jia, J., \& Zahorik, A. (1999). What you don't know about customer-perceived quality: the role of customer expectation distributions. Marketing Science, 18(1), 77-92.

Samu, S., Krishnan, H. S., \& Smith, R. E. (1999). Using advertising alliances for new product introduction: interactions between product complementarity and promotional strategies. Journal of Marketing, 63(1), 57-74.

Schumann, J H., Wünderlich, N. V., \& Evanschitzky, H. (2014). Spillover effects of service failures in coalition loyalty programs: the buffering effect of special treatment benefits. Journal of Retailing, 90(1), 111-118.

Sheinin, D. A. (2000). The effects of experience with brand extensions on parent brand knowledge. Journal of Business Research, 49(1), 47-55.

Shugan S. M., Moon, J., Shi, Q., \& Kumar, N.
S. (2017). Product line bundling: why airlines bundle high-end while hotels bundle low-end. Marketing Science, 36(1), 124-139. Simonin, B. L., \& Ruth, J. A. (1998). Is a company known by the company it keeps? Assessing the spillover effects of brand alliances on consumer brand attitudes. Journal of Marketing Research, 35(1), 30-42.

Song, J. D. (2017). An exploratory study on the effect of price as an anchor on willingness-to-pay. Asia Marketing Journal, 18(4), 27-49.

Srinivasan, V. (1979). Network models for estimating brand-specific effects in multiattribute marketing models. Management Science, 25(1), 11-21.

Stigler, G. J. (1961). The economics of information. Journal of Political Economy, 69(3), 213-225.

Stock, A., \& Balachander, S. (2005). The making of a "hot product": a signaling explanation of marketers' scarcity strategy. Management Science, 51(8), 1181-1192.

Suh, J. Y., \& Park, S. B. (2009). Successful brand alliance and its negative spillover effect on a host brand: test of the cognitive response hypothesis. Advances in Consumer Research, 36, 243-247.

Sujan, M., \& Bettman, J. R. (1989). The effects of brand positioning strategies on consumers' brand and category perceptions: some insights from schema research. Journal 
of Marketing Research, 26(4), 454-467.

Swaminathan, V., Reddy, S. K., \& Dommer, S. L. (2012). Spillover effects of ingredient branded strategies on brand choice: a field study. Marketing Letters, 23(1), 237-251.

Teas, R. K. (1993). Expectations, performance evaluation, and consumers' perceptions of quality. Journal of Marketing, 57(4), 18-34.

Thorbjørnsen, H. (2005). Brand extensions: brand concept congruency and feedback effects revisited. Journal of Product \& Brand Management, 14(4), 250-257.

Tsai, M.-C., Lou, Y.-C., Bei, L.-T., \& Monroe, K. B. (2014). Position matters when we stand together: a linguistic perspective on composite brand extensions. Journal of the Academy of Marketing Science, 42(6), 680-701.

Vadillo, M. A., \& Matute, H. (2010). Augmentation in contingency learning under time pressure. British Journal of Psychology, 101(3), 579-589.

Vaidyanathan, R., \& Aggarwal, P. (2000). Strategic brand alliances: implications of ingredient branding for national and private label brands. Journal of Product \& Brand Management, 9(4), 214-228.

Van der Lans, R., Van den Bergh, B., \& Dieleman, E. (2014). Partner selection in brand alliances: an empirical investigation of the drivers of brand fit. Marketing Science, 33(4), 551-566.
Van Riel, A. C. R., Lemmink, J., \& Ouwersloot, H. (2001). Consumer evaluations of service brand extensions. Journal of Service Research, 3(3), 220-231.

Venkatesh, R., \& Mahajan, V. (1997). Products with branded components: an approach for premium pricing and partner selection. Marketing Science, 16(2), 146-165.

Venkatesh, R., Mahajan, V., \& Muller, E. (2000). Dynamic co-marketing alliances: when and why do they succeed or fail. International Journal of Research in Marketing, 17(1), 3-31.

Voss, K. E., \& Tansuhaj, P. (1999). A consumer perspective on foreign market entry: building brands through brand alliances. Journal of International Consumer Marketing, 11(2), 39-58.

Votolato, N. L., \& Unnava, H. R. (2006). Spillover of negative information on brand alliances. Journal of Consumer Psychology, 16(2), 196-202.

Walchli, S. B. (2007). The effects of betweenpartner congruity on consumer evaluation of co-branded products. Psychology \& Marketing, 24(11), 947-974.

Wan, L. C., Hui, M. K., \& Wyer Jr, R. S. (2011). The role of relationship norms in responses to service failures. Journal of Consumer Research, 38(2), 260-277.

Ward, J. C., Bitner, M. J., \& Barnes, J. (1992). Measuring the prototypicality and meaning of retail environments. Journal of Retailing, 
68(2), 194-220.

Washburn, J. H., Till, B. D., \& Priluck, R. (2000). Co-branding: brand equity and trial effects. Journal of Consumer Marketing, 17(7), 91-604.

Washburn, J. H., Till, B. D., \& Priluck, R. (2004). Brand alliance and customerbased brand-equity effects. Psychology \& Marketing, 21(7), 487-508.

Weber, K., \& Sparks, B. (2010). Service failure and recovery in a strategic airline alliance context: interplay of locus of service failure and social identity. Journal of Travel and Tourism Marketing, 27(6), 547-564.

Weiner, B. (2000). Attributional thoughts about consumer behavior. Journal of Consumer Research, 27(3), 382-387.

Woisetschlaeger, D., Michaelis, M., \& Backhaus, C. (2008). The "dark side" of brand alliances: how the exit of alliance members affects consumer perceptions. Advances in Consumer Research, 35, 483-490. 